\title{
Fényemittáló vegyületek előállítása és vizsgálata
}

\author{
RÁCZ Dávid* \\ Debreceni Egyetem, Alkalmazott Kémiai Tanszék, Egyetem tér 1., 4032 Debrecen, Magyarország
}

\section{Bevezetés}

A Debreceni Egyetem Alkalmazott Kémiai Tanszéke hosszú évtizedek óta foglalkozik polimerkémiai kutatásokkal, az utóbbi években pedig a speciális polimerek (fényemittáló és alakmemória polimerek) és egyéb intelligens anyagok fejlesztése került a fókuszpontba, így folyamatosan lépést tartva a kor tudományos kihívásaival. Az ilyen intelligens anyagok előállítása a kutatók régi álma, ugyanis ezek az élő szervezetekhez hasonlóan reagálnak bizonyos külső hatásokra (pl. fény, hőmérséklet, elektromos áram). $\mathrm{A} \mathrm{PhD}$ kutatómunkám során előállított és vizsgált fluoreszcens intelligens anyagok környezetük megváltozását a kibocsátott fényük színváltozásával jelzik.

A fluoreszcens festékanyagok elsősorban az orvosi diagnosztika és a bioanalitika nélkülözhetetlen reagensei, jelölőanyagként biomolekulákhoz kötve vizsgálják velük az anyagok szerkezetét, kölcsönhatásait, mozgását a szervezeten belül. Különleges jelentőséggel bír az úgynevezett szolvatokróm festékanyagok csoportja, esetükben ugyanis a kibocsátott fluoreszcencia hullámhossza és intenzitása függ a molekula közvetlen környezetének polaritásviszonyaitól. A jelenség oka, hogy a fényt abszorbeáló molekula alap- és gerjesztett állapota másképp szolvatálódik a különböző polaritású közegekben, és ez jelentős befolyással van az ilyen molekulák emissziós spektrumára is. ${ }^{1}$ A legfontosabb alkalmazási területeken, a bioanalitikában és a fluoreszcens mikroszkópiában a szolvatokróm festékanyagok segítségével a kibocsátott fluoreszcenciájuk színe alapján jól elkülöníthetőek a különböző polaritású sejt- illetve szövetrészek. ${ }^{2-4}$

A fényemittáló polimerek a fluoreszcens anyagok egy speciális csoportját képviselik. Legfontosabbak ezek közül is a konjugált polimerek, melyek gerjesztése fényen kívül (félvezető tulajdonságuknak köszönhetően) elektromos árammal is lehetséges, ennek megfelelően elsősorban képi megjelenítő eszközökben történő felhasználásukra folynak kiterjedt kutatások. Ezekkel különleges igények is könnyen kielégíthetők (pl. hajlékony hordozóra is felvihetők), ami egyrészt a polimerek kedvező tulajdonságainak (rugalmasság, szívósság, oldhatóság, jó alakíthatóság), másrészt a könnyű feldolgozhatóságuknak köszönhető. ${ }^{5-6}$ Legnagyobb jelentőséggel a kék fény kibocsátására képes fényemittáló polimerek bírnak, ugyanis a kék szinből más, kisebb energiájú szín is könnyen előállítható. ${ }^{7}$

\section{Kutatási eredmények}

\section{1. Új, amino-izocianonaftalin alapú fluoroforok}

$\mathrm{Az}$ elmúlt években kutatócsoportunk kifejlesztett egy új, szolvatokróm fluoreszcens vegyületcsaládot, melynek alapja az 1,5-diaminonaftalinból diklórkarbénnal, lúgos kloroformos oldatban előállított 1-amino-5-izocianonaftalin (ICAN, 1. ábra (1)), mely jelentős pozitív szolvatokróm effektust mutat.

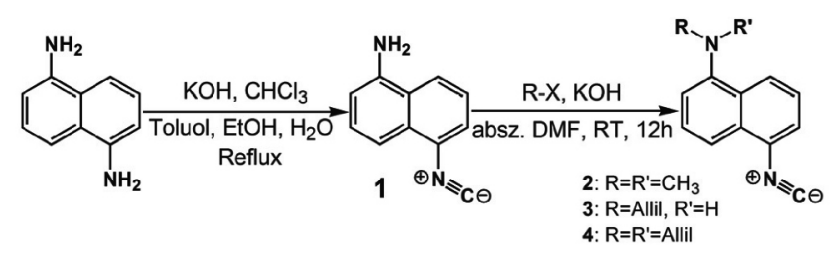

1. Ábra. Az 1-amino-5-izocianonaftalin (1) és alkilezett származékainak (dimetil (2), monoallil (3), diallil (4)) előállítása

A kiindulási 1,5-diamino- és az analóg szerkezetü 1,5-diizocianonaftalinnal ellentétben az ICAN emissziós maximuma a spektrum látható tartományába esik (2. ábra), hullámhossza hexánban a legalacsonyabb (409 nm), az alkalmazott legpolárosabb oldószerben, vízben pedig a legmagasabb $(513 \quad \mathrm{~nm})$. A fluoreszcencia kvantumhasznosítási tényező értéke jellemzően igen magas, 1,4-dioxánban $\Phi_{\mathrm{F}}=0,95$, de vízben is $\Phi_{\mathrm{F}}=0,04$ értékü, általánosságban véve csökken az oldószer polaritásának növekedésével.

Az abszorpciós spektrumokat különböző oldószerekben kvantumkémiai számításokkal is meghatároztuk az időfüggő sürüségfunkcionál elmélet (TD-DFT) alapján, melyek alakja jó egyezést mutatott a mért spektrumokkal. Az oldószerek polaritásának emissziós spektrumra gyakorolt hatását a Lippert-Mataga, a Kamlet-Taft és a Catalán egyenletekkel is modelleztük, az utóbbi kettő, melyek a specifikus kölcsönhatásokat is figyelembe veszik, jó közelítést szolgáltattak. Az ICAN fluoreszcenciáját ciklohexán/ tetrahidrofurán elegyben vizsgálva kedvezményezett oldódást figyeltünk meg, vagyis az ICAN oldószerburkában a THF mólaránya lényegesen nagyobbnak bizonyult, mint tömbfázisban.

\footnotetext{
a Tel.: +36 52 512-900/22454; Fax: +36 52 518-662; e-mail: racz.david@science.unideb.hu
} 


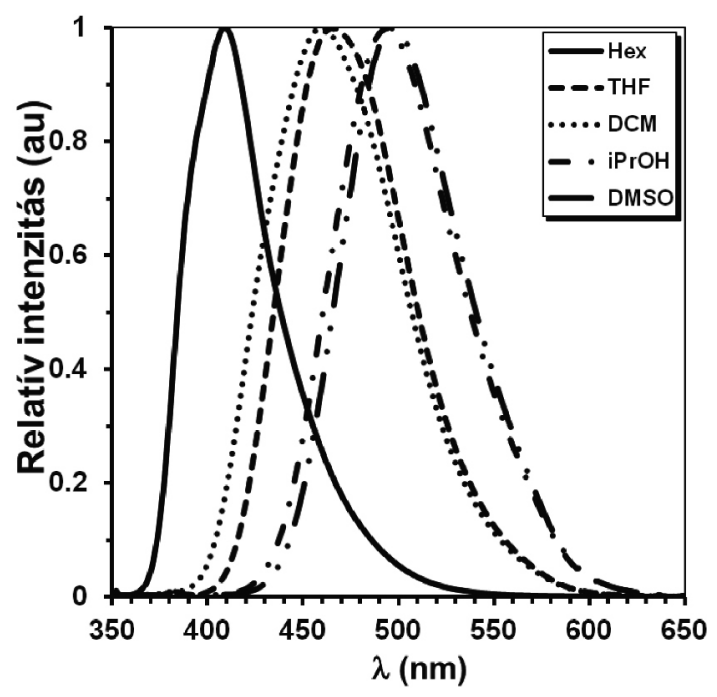

2. Ábra. Az 1-amino-5-izocianonaftalin emissziós spektruma hexánban (Hex), tetrahidrofuránban (THF), diklórmetánban (DCM), 2-propanolban (iPrOH) és dimetil-szulfoxidban (DMSO)

A gerjesztett állapot élettartama a lézer villanófény fotometriás vizsgálatok alapján a vizsgált oldószerek mindegyikében $10 \mathrm{~ns}$ nagyságrendbe esett, legrövidebb hexánban (6,4 ns), leghosszabb DMSO-ban (16,3 ns) volt.

Az N-alkilezett származékok (dimetil, mono- és diallil) a kiindulási vegyülethez hasonlóan viselkedtek, bár a szolvatokróm emissziós tartományuk valamivel szükebbnek bizonyult. A dialkil származékok gerjesztési spektruma egyszerübb szerkezetü, ezek esetében hiányzik a kisebb hullámhossznál lévő váll, ami a szabad amino hidrogének hiányával magyarázható, hiszen így nem képesek hidrogénkötés kialakítására az oldószerrel (3. ábra).

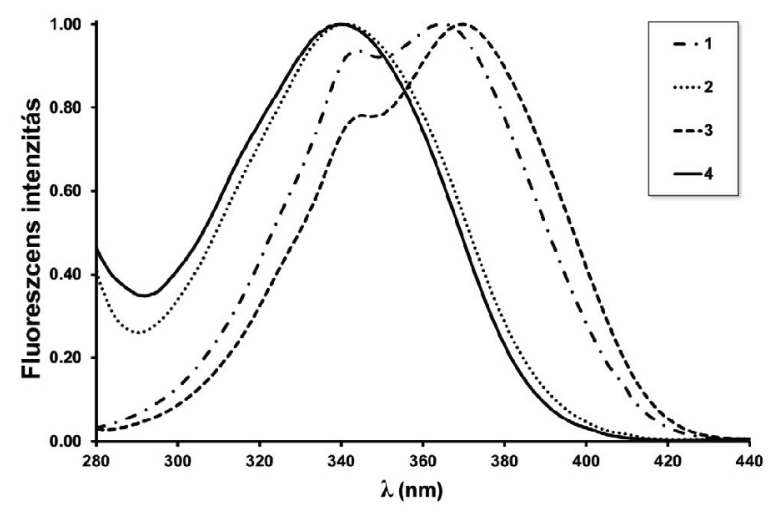

3. Ábra. Az ICAN (1), annak dimetil- (2), monoallil- (3) és diallil-származékának (4) normált gerjesztési spektrumai (THF, $20{ }^{\circ} \mathrm{C}$ )

Megállapítottuk, hogy molekuláris sajátságainál fogva az ICAN fluoreszcenciája apolárosabb környezetben intenzívebb. Ez a tulajdonsága a gyakorlati életben is jól hasznosítható, modellkísérletként az ICAN-t egy felületaktív anyag, a nátrium-laurilszulfát kritikus micellaképződési koncentrációjának meghatározására használtuk fel. Cmc felett az ICAN a képződő micellák apoláros magjába ágyazódott be, melyet az emisszió jelentős mértékű kék irányú eltolódása és a kvantumhasznosítási tényező növekedése jelzett. ${ }^{8}$
Az ICAN és annak szabad amin hidrogénnel rendelkező monoalkilezett származékai különleges fluoreszcencia kioltási jelenséget mutattak piridinnel. Kis mennyiségú piridin hatására ugyanis a fluoreszcencia intenzitás drasztikusan lecsökken, nagyobb koncentráció esetén azonban jelentősen visszaemelkedik. Ezt egy piridinnel hidrogénkötésen keresztül kapcsolódó nem fluoreszkáló alapállapotú komplex és egy fluoreszcenciát kibocsátó $\pi$-szendvicskomplex egyidejű jelenlétével magyaráztuk, a két forma között egyensúlyt feltételeztünk. ${ }^{9}$

\subsection{Fenantrolin-funkcionalizált polimerek és Fe(II)- komplexeik}

Tanszékünkön hosszú idő óta kiterjedt kutatások folynak különböző funkcionalizált poli(izobutilén) (PIB) és poli(etilénlikol) (PEG) származékokkal kapcsolatban. Mindkét polimer nagy gyakorlati jelentőséggel bír, a PEG elsősorban poláris közegben, leginkább vízben, míg a PIB apoláris közegben, föleg szerves oldószerekben hasznosítható jól. Ezek mono- és bifenantrolin-funkcionalizált származékait Williamson-szintézissel állítottuk elő. A fenantrolin ugyanis kék fény emissziójára képes vegyület, emellett közismert jó komplexképző képességéről is bizonyos fémionokkal, mely a fényemisszió szabályozására is alkalmas lehet. A várakozásoknak megfelelően azt tapasztaltuk, hogy mind a PEG-, mind a PIB-fenantrolin származékok stabil komplexeket képeznek $\mathrm{Fe}^{2+}$-ionokkal. A komplexképződést UV-Vis spektrofotometriával vizsgáltuk a PEG fenantrolin származékainak vizes oldatában. A komplexképződés minden esetben gyakorlatilag kvantitatívnak bizonyult a képződő komplexek valószínüleg igen nagy egyensúlyi együtthatójának köszönhetően, a fenantrolin végcsoportok és a $\mathrm{Fe}^{2+}$-ionok arányát 3:1-nek határoztuk meg. A phen-komplexek moláris abszorpciós koefficiense $\varepsilon=10000$ $\mathrm{M}^{-1} \mathrm{~cm}^{-1}$ nagyságrendü (4. ábra).

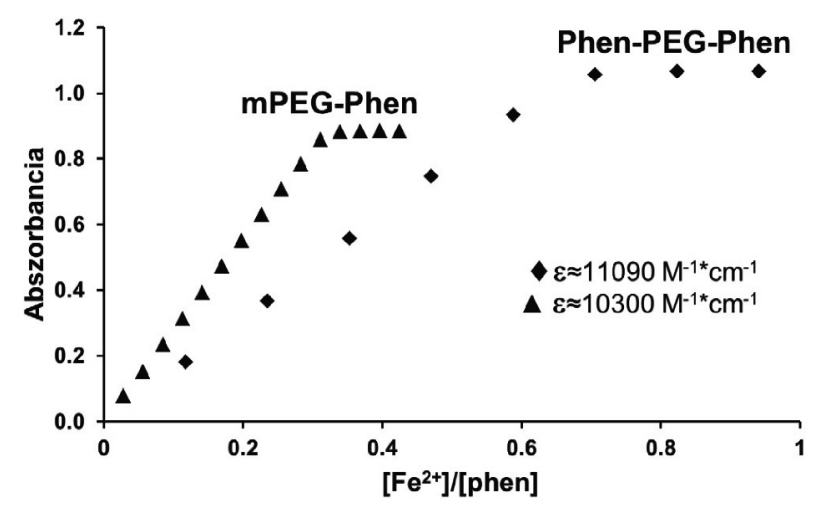

4. Ábra. Az abszorbancia változása 515 nm-en a hozzáadott Fe(II)-ionok és a polimer fenantrolin funkciós csoportjai mólarányának függvényében, vizes oldatban. Poli(etilénglikol)- $\alpha$-monometil- $\omega-5[1,10]$ fenantrolin éter ( $\left.\mathbf{\Delta}, \mathrm{c}=2,710^{-4} \mathrm{M}, \mathrm{mPEG}-\mathrm{Phen}\right)$. Poli(etilénglikol)-5[1,10]fenantrolin diéter $\left(\boldsymbol{\uparrow}, \mathrm{c}=1,25 \bullet 10^{-4} \mathrm{M}\right.$, Phen-PEG-Phen).

Az ESI-TOF mérések alapján a PEG-biszfenantrolin $\mathrm{Fe}^{2+}$-ionokkal keresztkapcsolt szerkezeteket hoz létre, míg a PEG-monofenantrolin vízben aggregátumokat képez. A cmc-t és az aggregátumok hidrodinamikai sugarát dinamikus fényszórás méréssel határoztuk meg. 


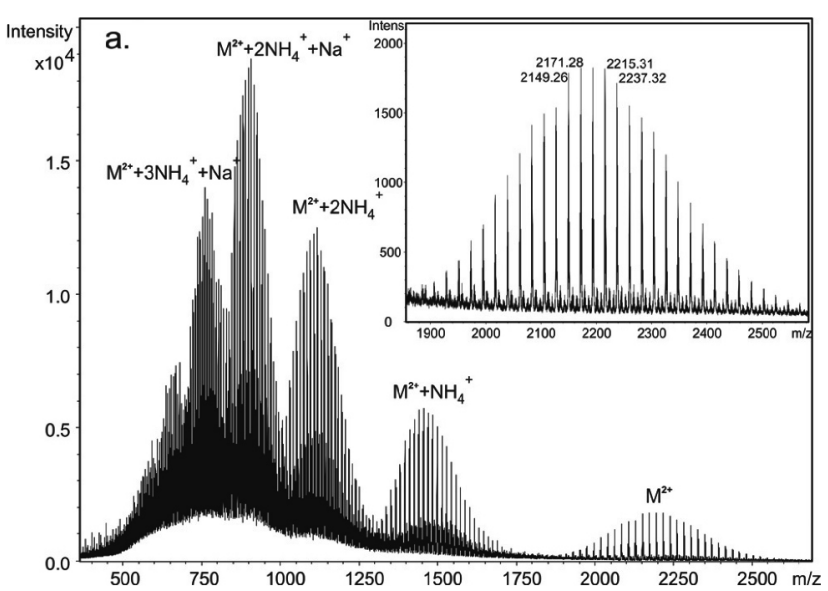

5. Ábra. A PEG-monofenantrolin származék $\mathrm{Fe}^{2+}$-vel alkotott komplexének ESI-TOF tömegspektruma. Az $\mathrm{M}^{2+}$ az $\left[(\mathrm{mPEG}-\mathrm{phen})_{3} \mathrm{Fe}\right]^{2+}$-t jelöli.

A polimerek monofenantrolin származékaiból képződő komplexket ESI-TOF tömegspektrométerrel vizsgáltuk, melyek ezzel a módszerrel egyértelmüen azonosíthatóak voltak (5. ábra). A PEG-biszfenantrolin és Mohr-só reakciójából vörös színü, gumiszerű polimer hálózatot hoztunk létre, a vízoldható ionomert UV-Vis spektrofotometriás módszerrel és mikroszkóppal is megvizsgáltunk. Az ionomer szerkezetnek köszönhetően a $\mathrm{Fe}^{2+}$-ionok levegön is stabilnak bizonyultak, nem tapasztaltunk oxidációt. A PIB-biszfenantrolint, mivel csak apoláris szerves oldószerekben oldható, diklórmetánban oldva elegyítettük a Mohr-só vizes oldatával, melynek eredményeként nagy mennyiségü gélt kaptunk, mely állás közben jelentős mennyiségű vizet veszített. A megszáradt polimer hálózatot nem sikerült semmilyen, egyébként PIB oldására alkalmas oldószerben feloldani, ami térhálós szerkezet kialakulását valószínűsíti. Míg a PIB-monofenantrolin $\mathrm{Fe}^{2+}$-komplexei csak apoláros oldószerekben, a PEG-monofenantrolin $\mathrm{Fe}^{2+}$-komplexei poláros és apoláros oldószerekben is egyaránt jól oldódnak, ezért akár fázistranszfer-katalizátorként is ígéretes lehet alkalmazásuk. ${ }^{10}$

\subsection{Amfifilikus, kék fényt emittáló glükozilezett polinaftalén-fenilén kopolimer}
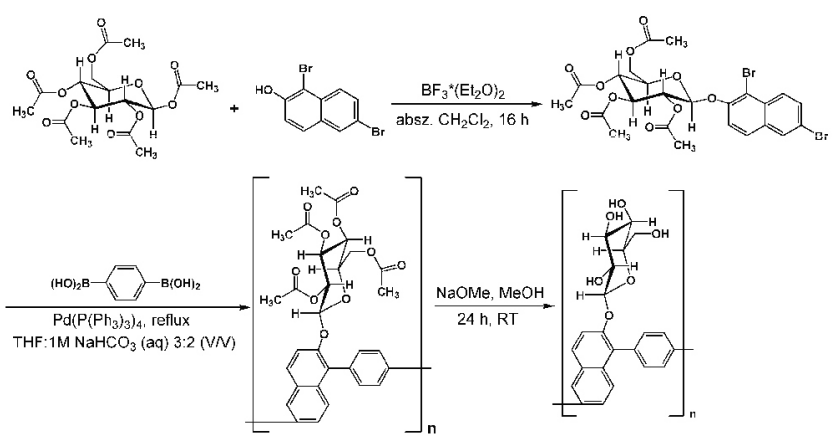

6. Ábra. A poli(2-glükopiranozil-1,6-naftalén-1,4-fenilén) szintézise
Ismert, hogy a naftalin bizonyos származékai intenzív kék fluoreszcenciával rendelkeznek. Fényemittáló polimerekként való elterjedését azonban jelentősen akadályozza, hogy az ilyen polimerek nagyon rossz oldhatósággal rendelkeznek. Kutatásunk szorán ezt a hátrányos tulajdonságot a könnyen hozzáférhető, megfelelően nagy térkitöltésű glükóz szubsztituens naftalin monomerre való felvitelével sikerült orvosolnunk. Az így kapott 1,6-dibróm-2-naftil-tetra-O-acetil- $\beta$-D-glükozid és benzol-1,4dibórsav közötti Suzuki-polikondenzációval glükozilezett naftalén-fenilén típusú kopolimert állítottunk elő (6. ábra).

Ezzel elsőként poli(2-(tetra-O-acetil-glükopiranozil) -1,6-naftalén-1,4-fenilén)-t kaptunk, melyet azután teljesen dezacetileztünk. A polimert gélpermeációs kromatográfiai és ${ }^{1} \mathrm{H}$ NMR spektroszkópiai eljárások alapján jellemeztük. A glükozilezett kopolimer poláros oldószerekben, így metanol/tetrahidrofurán elegyben és akár vízben is oldhatónak bizonyult, ezen felül mindkét oldószerben

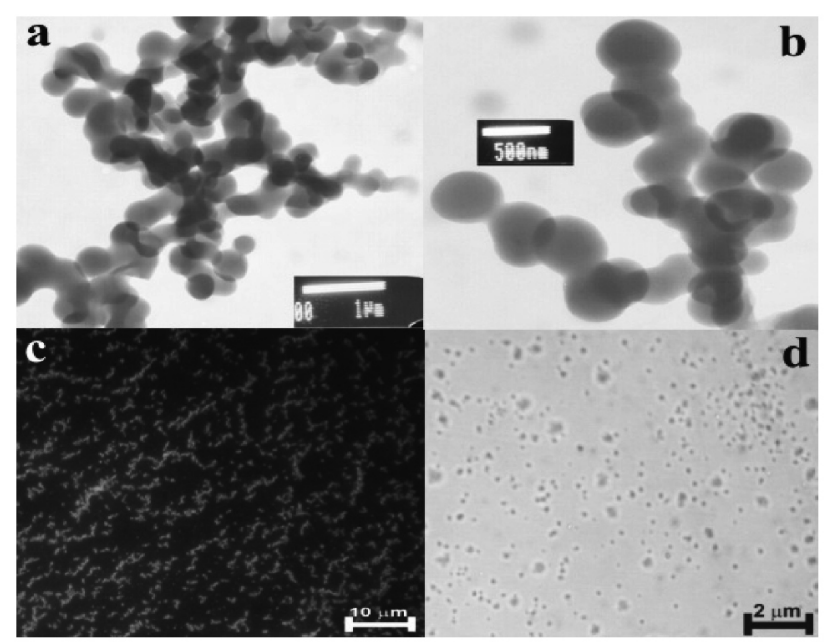

önszerveződést is megfigyeltünk.

7. Ábra. A poli(2-glükopiranozil-1,6-naftalén-1,4-fenilén) elektronmikroszkópos képe (a), ennek nagyított részlete (b); A kopolimerből kialakult aggregátumok optikai mikroszkópos képe $\lambda=320-360 \mathrm{~nm}$-es UV-sugárzással gerjesztve (c) illetve áteső fényben (d)

Transzmissziós elektronmikroszkóppal, szilárd fázisban egységes méretű nanogömböket láttunk, $460 \mathrm{~nm}$ átlagos átmérővel. A nanogömbök kék színü fluoreszcenciáját optikai mikroszkóp alatt is meg lehetett figyelni (7. ábra). Kimutattuk, hogy a kopolimer vizes közegben is képez aggregátumokat, melyek kritikus micellaképződési koncentrációját és hidrodinamikai sugarát dinamikus fényszórás-méréssel határoztuk meg.

Tanulmányoztuk a kopolimer fluoreszcenciás tulajdonságait is. Az emissziós fluoreszcenciasáv maximuma az acetilezett kopolimer esetében $\lambda_{\mathrm{em}}=396 \mathrm{~nm}$, ennek dezacetilezett származékánál pedig az alkalmazott oldószertől függően $\lambda_{\text {em }}=403-405 \mathrm{~nm}$ volt. Az emissziós sáv maximuma és alakja egyaránt oldószerfüggést mutatott, ami a fentiek ismeretében a kopolimer önszerveződésével magyarázható. Valószínűsíthető az is, hogy az emissziós sáv vörös irányú eltolódása és kiszélesedése is az önszerveződés következménye, és a polimer láncok között létrejövő $\pi$-kölcsönhatásnak tulajdonítható. 
Az előállított glükozilezett kopolimer jó oldhatósága és önszerveződő képessége miatt tervezett, jól meghatározott szerkezetü felületi struktúrák létrehozását teszi lehetővé, emissziós spektrumának befolyásolhatósága révén pedig a kék fényt emittáló polimerek egy igen ígéretes képviselője lehet. $^{11}$

\section{4. Új, egyszerű polikondenzációs eljárás kénhidas izoindol-fenilén alapú, kék fényt emittáló kopolimerek előállítására}

Bár a poliizoindolok elektronikai szempontból kedvező tulajdonságokkal rendelkező, kék-kékeszöld színü fény emissziójára képes anyagok, instabilitásuk miatt mégsem terjedtek el szélesebb körben. A stabilabb N-alkilezett származékokat korábban bonyolult eljárásokkal, különleges katalizátorokkal tudták csak elóállítani, melyek ha a termékben maradnak, komoly problémát okoznak. ${ }^{12-13}$

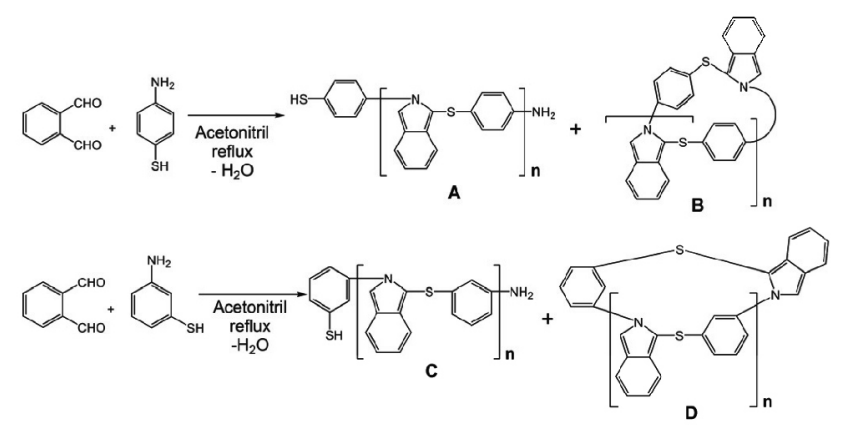

8. Ábra. A poli[(1,2-izoindolén)-(1-szulfán-4-fenilén)] (felső) és a poli[(1,2-izoindolén)-(1-szulfán-3-fenilén)] (alsó) eloállítása; A és $\mathbf{C}$ a lineáris, B és D a gyürüs termékeket jelöli

Kutatócsoportunk az analitikában elterjedt, aminok ftálaldehiddel történő mennyiségi meghatározásához használt reakció alapelvét felhasználva egy új, egyszerü, katalizátormentes polikondenzációs eljárást dolgozott ki orto-ftálaldehid (OPA) és 3- illetve 4-aminotiofenol között, mellyel sikerült poli[(1,2-izoindolén)-(1-szulfán-4-fenilén)]-t és poli[(1,2-izoindolén)-(1-szulfán-3-fenilén)]-t tisztán, jó kitermeléssel elöállítanunk (8. ábra). A polikondenzációs reakció oldószerfüggőnek bizonyult, egyedül acetonitrilben, nyomnyi mennyiségű víz jelenlétében ment végbe megfelelően. Mivel a képződött polimerek rosszul oldódnak acetonitrilben, az elérhető molekulatömeg korlátozott. A molekulatömeget csökkenti a gyürüképződés is, mely különösen meta-aminotiofenol alkalmazása esetén jelentősebb mértékü.

Vizsgáltuk a monomerek egymáshoz viszonyított arányának polikondenzációra gyakorolt hatását is, de nem bizonyult érzékenynek az arányok változtatására, azonban az OPA nagy feleslege kerülendő. MALDI-TOF tömegspektrometriás módszerrel a kopolimereken amin és tiofenil végcsoportokat mutattunk ki, valamint a gyürüs termékek jelenlétét is sikerült bizonyítani (9. ábra).
A kopolimerek NMR-vizsgálatával a térszerkezeti modellezéssel is valószínüsített, nagymértékben csavarodott szerkezet tényét erősítettük meg, ugyanis egy különleges, ortogonális $\sigma-\pi$ kölcsönhatást figyeltünk meg az aromás gyürük között.

A kopolimerek oldata kék fényemissziót mutatott, az emissziós fluoreszcenciasáv maximuma $\lambda_{\mathrm{em}}=448 \mathrm{~nm}$-nél található az 1,4-, míg $\lambda_{\mathrm{em}}=426$ nm-nél az 1,3-kopolimer esetében. Az előállított izoindol alapú kopolimerek tehát jó modellvegyületként szolgálhatnak hasonló szerkezetü új, hatékony, kék fényt emittáló polimerek fejlesztéséhez. ${ }^{14}$

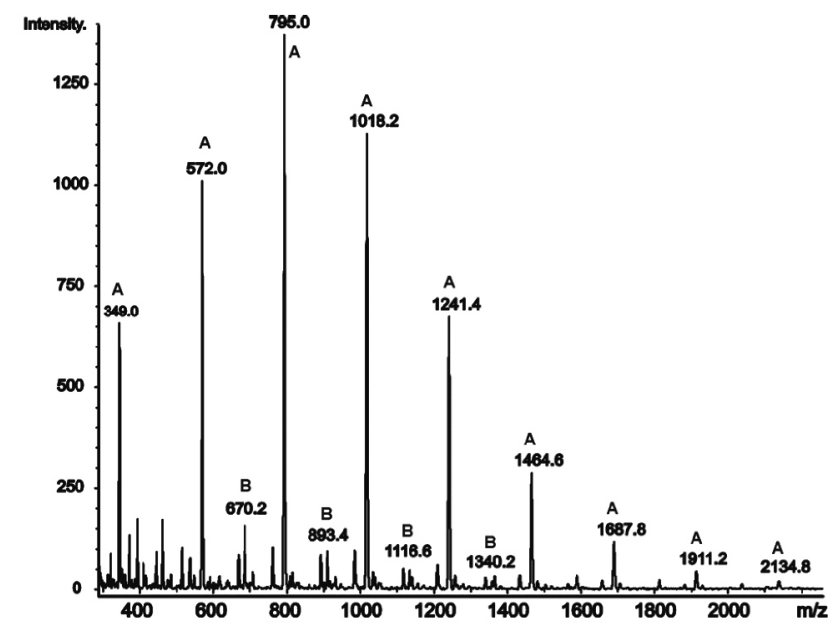

9. Ábra. A poli[(1,2-izoindolén)-(1-szulfán-4-fenilén)] MALDI-TOF tömegspektruma. Az A és B sorozat a 8. ábra szerinti lineáris (A) illetve gyürüs (B) termékeket jelölik

Tanszékünkön a jövöben is folytatjuk a fényemittáló intelligens anyagokkal kapcsolatos kutatásokat, különösen a naftalin és izoindol alapú polimerek fejlesztése területén van még számtalan kiaknázatlan lehetőség. Tervezzük továbbá az amino-izocianoaril vegyületcsalád bővítését is, és biológusok bevonásával vizsgáljuk a sejtfestékként való alkalmazásuk lehetőségét is.

\section{Köszönetnyilvánítás}

Hálás köszönettel tartozom témavezetőmnek, Dr. Kéki Sándornak kutatómunkám során nyújtott segítségéért, folyamatos támogatásáért, továbbá Dr. Nagy Miklósnak, aki nélkül ez a munka nem jöhetett volna létre. Köszönöm a következő pályázatoknak a kutatásainkhoz nyújtott anyagi segítséget: OTKA K-72524, OTKA K-101850, OTKA K-116465, TÁMOP-4.2.2.A-11/1/KONV-2012-0036, NKFI-116465. 


\section{Hivatkozások}

1. Lakowicz, J. R. Principles of Fluorescence Spectroscopy, 3rd ed. Springer: New York, 2006, pp 205. https://doi.org/10.1007/978-0-387-46312-4_6

2. Zhang, J.; Campbell, R. E.; Ting, A. Y.; Tsien, R. Y. Nat. Rev. Mol. Cell. Biol. 2002, 3, 906-918.

https://doi.org/10.1038/nrm976

3. Fernández-Suárez, M.; Ting, A. Y. Nat. Rev. Mol. Cell. Biol. 2008, 9, 929-943. https://doi.org/10.1038/nrm2531

4. Ntziachristos, V. Annu. Rev. Biomed. Eng. 2006, 8, 1-33. https://doi.org/10.1146/annurev.bioeng.8.061505.095831

5. Bernius, M. T.; Inbasekaran, M.; O'Brien, J.; Wu, W. $A d v$. Mater. 2000, 12, 1737-1750.

https://doi.org/10.1002/1521-4095(200012)12:23<1737::AI D-ADMA1737>3.0.CO;2-N

6. Zheng, H.; Zheng, Y.; Liu, N.; Ai, N.; Wang, Q.; Wu, S.; Zhou, J.; Hu, D.; Yu, S.; Han, S.; Xu, W.; Luo, C.; Meng, Y.; Jiang, Z.; Chen, Y.; Li, D.; Huang, F.; Wang, J.; Peng, J.; Cao, Y. Nat. Commun. 2013, 4, 1971. https://doi.org/10.1038/ncomms2971

7. Kim, D. Y.; Cho, H. N.; Kim, C. Y. Prog. Polym. Sci. 2000, 25, 1089-1139.

https://doi.org/10.1016/S0079-6700(00)00034-4

\section{Synthesis and investigation of light emitting compounds}

A new fluorophore was prepared by the reaction of 1,5-diaminonaphtahalene with dichlorocarbene in basic chloroform solution. The resulting 1-amino-5-isocyanonaphtahalene showed strong positive solvatochromic effects. The emission maxima fell in almost every case in the visible region of the spectrum (Figure 1). The solvatochromic range was between $409 \mathrm{~nm}$ (hexane) and 513 $\mathrm{nm}$ (water). The fluorescence quantum efficiency varied between $\Phi_{\mathrm{F}}=0.95$ (1,4-dioxane) and $\Phi_{\mathrm{F}}=0.04$ (water). The shape of the absorption spectra in different media was calculated using time-dependent density function quantum chemical model. The Lippert-Mataga plot, the Kamlet-Taft and the Catalán equation were applied to describe the solvent polarity effect on the emission spectra. The phenomenon of preferential solvation was detected in cyclohexane/THF solutions of ICAN. The fluorescence lifetimes were observed between 6.4 ns (hexane) and 16.3 ns (dimethyl sulfoxide). Derivatives with alkyl substituents have similar properties to that of the starting compound, however their solvatochromic emission region is slightly narrower. The differences in the absorbance spectra of the dialkylated molecules can be explained by the lack of the free amine N-H hydrogens, therefore the missing ability to form hydrogen bonds. It was demonstrated that ICAN can be applied for the cmc determination of surfactants such as sodium lauryl sulfate (SLS) with long nonpolar chain.

Mono and diphenanthroline-terminated poly(ethylene glycol)s and polyisobutylenes were prepared using the Williamson synthesis. It was shown that both PIB and PEG-phenanthrolines form strong complexes with $\mathrm{Fe}^{2+}$ ions. The complex formation was quantitative in each case, the ratio of the phenanthroline termini and $\mathrm{Fe}^{2+}$ ions was $3: 1$. Molar absorption coefficients were determined for PEG
8. Rácz, D.; Nagy, M.; Mándi, A.; Zsuga, M.; Kéki, S. J. Photoch. Photobiol. A. 2013, 270, 19-27. https://doi.org/10.1016/j.jphotochem.2013.07.007

9. Nagy, M.; Rácz, D.; Lázár, L.; Purgel, M.; Ditrói, T.; Zsuga, M.; Kéki, S. ChemPhysChem 2014, 15, 3614-3625. https://doi.org/10.1002/cphc.201402310

10. Nagy, M.; Zsuga, M.; Rácz, D.; Kéki, S. J. Polym. Sci. Pol. Chem. 2010, 48, 2709-2715. https://doi.org/10.1002/pola.24054

11. Nagy, M.; Rácz, D.; Daróczi, L.; Lukács, B.; Jóna, I.; Zsuga, M.; Kéki, S. Macromol. Chem. Phys. 2011, 212 , 1891-1899.

12. Ding, Y.; Hay, A. S. J. Polym. Sci. A Polym. Chem. 1999, 37, 3293-3299. https://doi.org/10.1002/(SICI)1099-0518(19990815)37:16<3 293::AID-POLA27>3.0.CO;2-N

13. Gauvin, S.; Santerre, F.; Dodelet, J. P.; Ding, Y.; Hill, A.R.; Hay, A. S.; Anderson, J.; Armstrong, N. R.; Gorjanc, T. C.; D’Iorio, M. Thin Solid Films 1999, 353, 218-222. https://doi.org/10.1016/S0040-6090(99)00391-0

14. Nagy, M.; Rácz, D.; Herczegh, P.; Batta, G.; Deák, G.; Lukács, B.; Jóna, I.; Zsuga, M.; Kéki, S. Eur. Polym. J. 2013, 49, 549-557.

https://doi.org/10.1016/j.eurpolymj.2012.10.021

complexes and were found to be $\varepsilon=11090 \mathrm{M}^{-1} \mathrm{~cm}^{-1}$ and $\varepsilon=10300 \mathrm{M}^{-1} \mathrm{~cm}^{-1}$ for the bisphenantroline and the monophenantroline PEG-derivative, respectively. The bisphenantroline PEG-derivative was shown to form cross-linked structure with $\mathrm{Fe}^{2+}$ ions, while the monophenantroline PEG-derivative was found to form aggregates in water. In the case of monofunctional ligands single complexes with $\mathrm{Fe}^{2+}$ ions can be clearly identified in the ESI-TOF mass spectra. A red-colored rubbery polymer network was created from the bisphenantroline PEG-derivative and the Mohr's salt. A well-defined microstructure was found according to optical microscopic studies of the layer. Well controlled structure was prepared from the bisphenantroline PIB-derivative and $\mathrm{Fe}^{2+}$ ions in a heterophase reaction.

A glucosylated naphthalene-phenylene-type copolymer was prepared by the Suzuki polycondensation of 1,6-dibromo-2naphthyl tetra-O-acetyl- $\beta$-D-glucoside and benzene-1,4diboronic acid, which was then deacetylated to obtain poly(2-glucopyranosyl-1,6-naphthalene-1,4-phenylene). The acetylated copolymer showed self-assembly behavior in $\mathrm{MeOH} / \mathrm{THF}$ mixture and in aqueous media. The formation of uniform sized nanospheres in solid phase having an average diameter of $460 \mathrm{~nm}$ was detected by transmission electron microscopy. The nanospheres showed blue fluorescence under optical microscope (Figure 2.). It was shown that the copolymer forms aggregates also in aqueous medium. Using dynamic light scattering method, the critical micelle concentration and hydrodynamic radius of the aggregates were determined. The fluorescence properties of the copolymer were also studied. Emission spectra were recorded and the emission maximum was determined. $\lambda_{\max }=396 \mathrm{~nm}$ was found for the acetylated and $\lambda_{\max }=403-405 \mathrm{~nm}$ for the desacetylated form depending on the 
solvent applied. The emission maximum and the shape of the emission peak showed solvent-dependence that can be attributed to the self-assembly of the copolymer. It was shown that the red shift and broader emission peak can be attributed to a specific $\pi$-interaction between the polymer chains due to self-assembly.

Poly[(1,2-isoindolene)-(1-sulfane-4-phenylene) $]$ and poly [(1,2-isoindolene)-(1-sulfane-3-phenylene)] new isoindole based copolymers were prepared in a simple polycondensation reaction between ortho-phthalaldehyde and 4or 3-aminothiophenol. The reaction proceeds under mild conditions without the presence of any catalyst. The reaction gives the pure copolymers with high yields. The polycondensation was found to be largely solvent dependent. It proceeds well only in acetonitrile in the presence of trace amounts of water. Unfortunately, the copolymers are insoluble in acetonitrile therefore the obtainable molecular weight is limited. The other molecular weight limiting factor can be cyclization when meta-aminothiophenol is applied. MALDI-TOF MS investigation showed the presence of amino and thiophenyl endgroups, while the formation of cyclic product could also be detected (Figure 3). NMR studies indicated a largely twisted structure, where orthogonal $\sigma-\pi$ interactions are present. Optical study of the copolymers showed blue-light emission in solution with $\lambda_{\mathrm{em}}=448 \mathrm{~nm}$ for the 1,4- and $\lambda_{\mathrm{em}}=426 \mathrm{~nm}$ for the 1,3-copolymer. 